\title{
A Study on Communicative Function of Euphemism in Political Language
}

\author{
Si-Mo JIA \\ Shandong Women's University \\ 2399,University Road,the University Science and Techonology Park \\ Changqing District,Jinan City, Shandong Province,China \\ Tel:+8618763996229 \\ Simo2007@163.com
}

Key words: Euphemism, communicative function, political language,

\begin{abstract}
Euphemism is a universal language phenomenon in the development of human beings' society. In the social interaction, politeness and courtesy are essential factors to sustain and promote the communication. There is no doubt that politics is the field that enjoys numerous usages of euphemism and the study of it has gained more concerns in recent years. This paper firstly illustrates the classification and the corresponding covering items of euphemism in English, namely as traditional ones and stylistic ones. Then, together with the detailed sentences adopted from the previaling political Newspaper, this paper collects and analyzes the usage and the communicative function of some euphemism appearing in these sentences. At last, this paper summarizes the concrete assiatance of these euphemism in the political dialogue which are trying to justify the immoral acts and win the fellow citizens' support.
\end{abstract}

\section{Introduction}

Euphemism is a kind of rhetoric method to beatify things that may offend or cause unpleasant feelings for the listeners. Generally speaking, it enjoys three functions, firstly, it is used as the substitution of some taboos in the daily conversations in order to smmoth the on-going of the dialogue. Secondly, it covers the function of politeness, especially in the field of business, the usage of euphemism would save the faces of both sides and promote the deal of businesss. Thirdly, it have the function of dissimulation, especially in the field of politics, some politicians would adopt the usage of euphemism to realize its deception function and make the audience or opponents better accept their views.

\section{Function of Euphemism}

\section{Traditional Euphemism:}

Religious euphemisms: The Christians often use the words gosh and gee as the substitution when they have to refer to their God-Jesus, because they are afraid that if they do so, they would violate the principles in Ten Commandments, which is the highest behavioral standard in their eyes(Newsman\&Silver,1983). Euphemisms for deities as well as for religious practices and artifacts date to the earliest of written records. At that time, due to the limitation of scientific terms, many mysterious phenomenons were classified into the creation of gods or goddess. The situation of taboo came from the worship and fear of super nature. To do it is to protect the names of sacred names, rituals and concepts related to religion. In the eyes of Western people, they believed God had the magic power and controlled everything in the world. So they created many euphemisms when they had to mention him. Although with the development of science, the religious euphemisms are less than before; their existences are still tightly related to religious belief and social habits.

Excretory euphemisms: The excrement no matter from animals or human beings are regarded as taboos which are better to be avoided in a conversatioon, the detailed words are such as manure, 
which refers to the excrement from an animal and are used as the fertilizers for the plants. Or other words, such as piss and shit, which are the excrements form human beings, are better to be cut off in order to avoid embrassment or unplensantness for the speakers and listeners.

Also, in other nationality's language, it is better to use graceful words and to reduce the usage of unpleasant elements and add more pleasant or happy elements into the conversation when people have to refer to this kind of contents.

Sexual euphemisms: People often use some other words to replece or beautify things that are related to the sex organs or sex procedure, for example, the words Groin, crotch, and loins are often used as the euphemisms for the word genitals, for the Latin and Greek term for the word genitals literally means "shameful things". On the other hand, people also often used the words intercourse as the replacement of the words "fuck" and "screw"There are many euphemisms for birth control devices, for example, Condoms are known as "rubbers", "sheaths", "love gloves", "diving suits", "raincoats", "Johnnies" etc. Euphemisms are also common in reference to sexual orientations and lifestyles. For example in the movie "Closer" the character uses the euphemism "He valued his privacy" for homosexual and "He enjoyed his privacy" for a flamboyant homosexual(Leech\&Geoffrey,1983).Any word related to sex is considered as taboo. To say it directly is rude and impolite.

Euphemisms for death: English is a kind of language that covers numbers of euphemisms that are related to dying ,death, burial, or the servents or locations that deal with death. For example, someone who dies is better to be said as passed away, or kicked the bucket, etc. The corpse, which means the body of the dead people are once referred as shroud of clay, and the people who works in the modern funerary are once called as the loved one. There are also other euohemisms for killings which are neither respecful or playful, but are used as the medical terms. Words like this are terminate, wet work to take care of one and etc(Gelman,2008).Death is the word people regarded as the taboo, it is an irresistible physical and social phenomena. Death is unfortunate, especially in ancient society; people deem death as mysterious and fearful. Because of their fear of death, people fear and do not like to mention it.

\section{Stylistic Euphemisms}

Euphemisms in job titles: We use Sanitation engineer for janitor, or 'transparent-wall maintenance officer' for window cleaner(Langacker,1993).In order to avoid hurting people's esteem, people use many uplifting words to decorate the name of their jobs. In the field of workplace, respect plays an important role; the irrespective behavior is the most serious obstacle blocking the effective and efficient accomplishment of project.

School education: For obtuse, we say, He can do better job with help. For naughty, we say, over active and etc(Ramos,1998). Teachers' comments have subtler influence on students' psychology. The positive remarks will have active psychological implication on students and help to improve the better educational atmosphere.

Business field: we say pre-owned car for second-hand car, antiques for second-hand furniture, and tints for dye, etc(Bergen,2005).People feel rude to say words directly, so they change to an indirect, moderate and more acceptable way to express their ideas. In the field of business, it is important to keep a good mood and take care of others' attitudes. Just as a Chinese old saying says, the good atmosphere may produce fortune.

\section{The Application of Euphemism in the Political Field}

Euphemism prevailed in the field of politics. The euphemisms in common life are aimed to avoid taboo or for politeness, but the euphemism are aimed for disguise. Politicians are keen on to use euphemisms to relieve the stressful atmosphere, to drive people's attention away, to cover the truth and to decorate the reality. Most of these euphemisms used over exaggeration or hyperbole to express the thing which is easy to irritate people. 


\section{The Widening or Upgrading of The Meaning.}

e.g.: Canada, which has become strong and self-reliant through many years of benign neglect by the British, should become self-governing.

In this sentence, the phrase benign neglect means non-intervention. The meaning of this sentence is that without England's interference in Canadian domestic affairs, Canada has become an independent country economically and politically. To express the meaning in this way can avoid offending British and beautify what they have done to Canada.

Speaking at last night's banquet, Dr Owen said no one should be in any doubt about the true nature of the Sovit and Cuban intervention in the Horn of Africa and why it placed such a large question mark over the future of detente.

In this sentence, the phrase place such a large question mark over the future of détente is the euphemistic expression of to threaten the future international affairs. To express the meaning in this way can not only let the other side know the seriousness of this issue, but also can avoid damaging the feeling of both sides.

The president raised income taxes on the affluent back in 1993. But by meeting, even exceeding, Republican demands in capital gains this year, Clinton will be remembered as a president who saw widening gap between the rich and poor, and helped them widen further.

In this sentence, the phrase capital gain is to mean to reduce the taxation. Since President Cliton comes from the Democratic Party, he should pay attention to avoid using offensive words when he dealt with the issue of Republican Party.

It is the argument that today's political class is composed of unscrupulous careerists. That class is determined to purchase incumbency by bestowing on voters benefits financed by borrowing-that is, by cynically pushing into the unborn some of the costs of current consumption of government goods and services.

In this sentence, the careerist refer to crook and opportunist, to say it in this way look down upon the politicians but avoid the personal attack.

\section{The Abstraction of the Meaning.}

We have entered upon a period of uncertainty involving fairly high mobilization.

The speaker, Abraham Lincoln, want to express that we are now engaged in a civil war. He mentioned a period of uncertainty involving fairly high mobilization to avoid say the word war directly. Thus, his audience understood his meaning without being scared.

\section{Circumlocution}

e.g: Q(Reporter): But you are at peace with yourself, having made the decision that you are willing to sacrifice American lives in this case.

A (George Bush): No, I am not willing to sacrifice American lives. I do not like that formulation. What I am willing to do is to see these United Nations resolutions fully implemented.

Actually, the reporter asked a sharp question that the war may kill people, but the president cover the truth by using he did it to obey the UN's rules. He used to see these United Nations resolution fully implemented to replace the sacrifices of Americans. Thus, he strategically avoided answering the question and prettified his purposes.

\section{Conclusion}

To sum up, euphemism is the product of the development of social process. It is the symbolism of a high level of social civilization and morality. In our daily life, it can help us to create a relaxed atmosphere to improve the process of conversation, also, to protect the readers' and conversationalists' esteem and strengthen their confidence, to release the conflict and reduce the misunderstanding, then finally reach a positive result. Besides, its importance in the field of politics, military and diplomacy is more obvious. It may help the leaders or politicians to avoid the sharp issue and sensitive topics, send the message clearly to the listener without hurting their feeling and offending. On the other hand, as common people, knowing the knowledge of euphemism assists us 
understand better of the speakers' real meaning and to figure out the thing quickly. Nowadays, with the globalization, there is no doubt we will contact more with the outside world and have more communication with others, the usage of euphemism is more important. It absolutely will play an essential role in our life. Thus, the study of euphemisms has been concerned by more and more people. The study of it has both realistic and practical meaning.

\section{Reference}

[1] Leech\&Geoffrey.Principles of Pragmatics[M].London:Longman,1983.

[2] Modern Linguistics[M].Beijing: Foreign Language Teaching and Research Press,1999.

[3] Newman,J.S.\&Silver,C.G.A. Theasaurus of Euphemisms[M]. Beijing: World Publishing Corporation,1983.

[4] Neaman\&Judith. Kind Words[M].NewYork:Factsand File,1983.

[5] Pearson\&Judy Dornelia. Gender and Communication [M].NewYork: Wm .C .Brown Company Publishers, 1985.

[6]Gelman,S. A(2008). Generic Language in Parent -child Conversations[J].Language Learning and Development.2,70-79.

[7] Langacker,R (1993). Reference point constructions[J].Cognitive Linguistics.4,45-50.

[8]Ramos,F.Y (1998). Adecade of Relevance Theory[J].Journal of Pragmatics.3,60-65.

[9]Bergen,B (2005). Mental Simulation in Literal and Figurative Language Understanding. In Coulson,S(eds). The Literal and Nonliteral in Language and Thought.

[10] Radden G.\&Z.K.Vecses (1999). Towards a theory of metonymy.In K.Panther\&G.Radden(eds).

Metonymy in Language and Thought. 